\title{
Morpho-Anatomical Feature and Phytochemical Assessments of Lasia spinosa (L)Thwaites
}

\author{
M. ARYA LAKSHMI* G. VEDA PRIYAAND B. G. RAO ${ }^{1}$ \\ ${ }^{1}$ Pharmacognosy and Phytochemistry Research Division, Andhra University College of Pharmaceutical Sciences, Andhra Uni- \\ versity, Visakhapatnam-530003, ${ }^{2}$ Registrar, Adikavi Nannaya University Campus, Rajamahendravaram-533296, India
}

Lakshmi et al.: Anatomical Feature and Phytochemical Assessments of Lasia spinosa (L)Thwaites

\begin{abstract}
Standardization of a crude medication is necessary to determine the authenticity, consistency, and effectiveness of herbal medicines. Lasia spinosa (L) Thwaites belongs to Araceae. Ethanomedicinally, the entire plant used in folklore medicine for many medical uses such as cancer, constipation and rheumatism. The critical issue with herbal drug standardization is lack of adequate plant source recognition. Therefore, quality assurance criteria must be defined using pharmacognostic and phytochemical assessment. The present research investigated pharmacognostic, physicochemical, fluorescence and phytochemical parameters of the different plant parts. Such approaches are valuable tools to help complement the knowledge with its standardization and recognition and further work in the Ayurveda medicine system.
\end{abstract}

Key words: Standardization, Physicochemical, fluorescence, Pharmacognostic and phytochemical assessment, Lasia spinosa

Medicinal plants play a vital role in the modern systems of medicine intended for the treatment of various diseases. However, a significant hiatus, which has impeded the promotion in the usage of alternative medications in the developed countries, is due to a lack of scientific evidence and lack of rigid quality control profiles. Hence modern approach in the standardization of plant and its parts used for the medication is necessary for acceptance in the contemporary scientific world. Evolving reliable, sensitive and selective methods for the quality control of raw materials and finished products would help to have herbal medicines of consistent desired quality and efficacy. Lasia spinosa (L) Thwaites belongs to the family Araceae. The family Araceae consists of approximately 115 genera and 16 species which are aquatic plants. It is distributed in India, Sri-Lanka, South-east Asia and Malaysia. It is known as mulasari, kanta kachoramu by the local people of Andhra Pradesh. Plants are aquatic or terrestrial, short-stemmed spiny hairs with the underground rhizome. Lasia spinosa usually occurs in wet forests, open marshes, wetlands or in permanently standing water ${ }^{[1]}$. It is a large marsh plant with the stem stout $1 \mathrm{~m}$ high and the leaves are broadly arrow-shaped. Traditionally, rhizomes used for abortion, treatment of lymphadenitis, piles, stomach ache, snake and insect

*Address for correspondence

E-mail: maryalakshmi@gmail.com

September-October 2020

Indian Journal of Pharmaceutical Sciences bites, injuries and rheumatism. A decoction of leaves of Cinnamomum tamala with roots of Lasia spinosa is given in rheumatism. Crushed leaves applied to cuts and injuries as hemostatic; leaf juice taken to kill intestinal parasites and to get relief from menstrual pain; a preparation from leaf juice abortifacient; leaves and roots a remedy for piles. Veterinary medicine, juice of leaves and petioles mixed with water fed to cattle against throat infections. Magic, ritual, flowers of Elaeagnus latifolia with roots of Lasia spinosa and Machilus bombycina pounded and made into pills used against sorceries $^{[2]}$. Different parts of Lasia spinosa have been claimed ethnomedicinally to use as anti-rheumatoid arthritis, treatment of constipation ${ }^{[3]}$, anticestodals ${ }^{[4]}$, antioxidant ${ }^{[5]}$, antimicrobial, and cytotoxic ${ }^{[6]}$ in the management of different disease conditions. Few phytochemicals have been reported on this plant in the literature like alkaloids, carbohydrates, proteins, flavonoids, terpenoids, phenolic compounds, steroids, saponins, glycosides, ascorbic acid and tannins ${ }^{[7]}$.

This is an open access article distributed under the terms of the Creative Commons Attribution-NonCommercial-ShareAlike 3.0 License, which allows others to remix, tweak, and build upon the work non-commercially, as long as the author is credited and the new creations are licensed under the identical terms

Accepted 15 September 2020

Revised 09 September 2020

Received 17 June 2020

Indian J Pharm Sci 2020;82(5):891-901 
According to previous literature, there is no scientific data available to identify the actual plant material and to ensure its purity. Therefore, the present investigation on this plant has been accomplished to establish the pharmacognostic, physicochemical and phytochemical standards for evaluating the plant material, which could serve as a measure of authentication and quality control for commercial samples of the crude drug.

\section{MATERIALS AND METHODS}

\section{Collection and authentication of plant materials:}

The whole plants of Lasia spinosa (L) were collected from kommulamamidi, near kottapalli village, paderu in Visakhapatnam (Andhra Pradesh) in the month of November-December 2018. The plant materials were authenticated by Prof S.B.Padal, department of botany (Voucher specimen number 23302), Andhra University, Visakhapatnam. The collected plants were separated, and its parts like fruits, flowers, roots, rhizome, shoot and leaves are processed. The collected plant parts were dried under shade for ten days, coarsely powdered and passed through sieve no. 40 and stored in an airtight container for further study.

\section{Pharmacognostical evaluation:}

Morphological and histological characterization of the whole plant of Lasia spinosa was carried out.

\section{Chemicals and reagents:}

All the reagents used were of analytical grade obtained from Sigma Chemical Co. St. Louis, USA and Fine Chemicals Ltd., Mumbai, India.

\section{Morphological evaluation:}

The fresh matured parts of the plant were studied for their macroscopic characters such as size, shape, margin, apex, surface, colour, odour, taste, nature and texture and recorded ${ }^{[8]}$.

\section{Microscopic evaluation:}

All the qualitative and quantitative microscopic parameters of different plant parts were determined as per WHO guidelines on quality control for herbal drugs. The Microphotography was taken with the help of a Microscope (Nikon Microscope Eclipse 80i).

\section{Preparation of specimens:}

The freshly collected leaf, stem, flower, rhizome and root samples were fixed in FAA (Formalin $5 \mathrm{ml}+$ Acetic acid $5 \mathrm{ml}+70 \%$ ethyl alcohol $90 \mathrm{ml}$ ). After $24 \mathrm{~h}$ of fixing, transverse sections were hand-cut and stained with safranine, phloroglucinol and mounted in glycerin for observation under the microscope.

Sectioning-All plant part sections were cut with the help of a sharp blade. The cleared fine sections were transferred to a watch glass containing a staining solution (Safranin $1 \%$ solution). The sections were allowed to stain for 2-3 min then moved to a watch glass containing plain distilled water to wash away excess of the stain. The sections were then transferred to a clean micro slide and observed under the microscope. Shade dried plant material were powdered with the help of an electric grinder till a fine powder was obtained. This fine powder was subjected to powder microscopy studies, as per standard procedures mentioned ${ }^{[9]}$. The quantitative microscopy includes determination of stomatal index, stomatal number, palisade ratio, vein islet number, veinlet termination and powder analysis.

\section{Physico-chemical evaluation:}

Physicochemical parameters like ash values (total ash, acid-insoluble ash, and water-soluble ash), crude fibre content, moisture content, extractive values (alcohol soluble extractive, water-soluble extractive, pet ether soluble extractive, chloroform soluble extractive and hexane soluble extractive), swelling and foaming index were performed on the shade-dried powdered ${ }^{[10]}$. The behaviour of powder with different chemical and reagents, fluorescence analysis of the powdered plant material was subjected to examination under ultraviolet light after treatment with various chemical and organic reagents ${ }^{[11]}$.

\section{Preliminary phytochemical evaluation:}

The plant extracts of various parts were subjected to initial phytochemical screening for the detection of different plant constituents ${ }^{[12]}$.

\section{RESULTS AND DISCUSSION}

Leaves are mostly in basal or apical rosettes, simple, lanceolate, sagittate, or pinnatipartite, thorny along the veins with a membranous sheath at the base of the petiole. The size of the leaf is $30-45 \mathrm{~cm}$ long, up to 25 $\mathrm{cm}$ wide and 20-50 $\mathrm{cm}$ long petiole.

Flowers are small, Pink or violet or brown in colour, crowded on a usually fleshy spike and often enclosed in a large bract. They can be bisexual or unisexual. If they are unisexual, the males in the upper part of the spadix, whereas the females below. It is $6-8 \mathrm{~cm}$ long and 
3-3.5 cm wide flower, twisted spathe, short cylindrical spadix, hermaphrodite all fertile spathe long, narrow, fleshy, crooked, base convolute, deciduous, dense flower, perianth segments 4-6, obovate, tips curved stamens 4-6, filaments short, flat, ovary ovoid ovule solitary.

Fruit borne in cylindrical, crowded, quadrangular, apically densely spinose. Fruits are usually a fleshy berry, occasionally a spongy berry, a nutlet or a capsule. Seeds are large, $1 \mathrm{~cm}$ long in size, compressed-obovoid, testa thin, brown, hard, and somewhat rugose, embryo large, slightly curved, and endosperm present but only as a single cell layer.

The roots are adventitious and originate from the stem nodes. They are cylindrical, thick, and fleshy and emerge from below the vegetative bud the primary roots branch and form secondary and tertiary roots. Root hairs are present 40 to $50 \mathrm{~mm}$ from the root apex.

Rhizome is green, thick and spiny. New plants arise from the rhizome. The raphide content of the rhizome is slightly higher. Freshly cut rhizomes turn brownish on exposure to air. Fibrous strands are easily drawn out from the cut end of rhizomes, and these represent the spiral thickening of the vessel elements. Morphological characteristics of the various parts of Lasia spinosa were observed [fig. 1].

The transverse section of the leaf contains Lamina and Midrib [fig. 2(A)]. Lamina of the leaf is dorsoventral in nature containing upper epidermis, lower epidermis and mesophyll. The upper epidermis contains singlelayered polygonal and irregular cells with distinct cuticle covered with covering trichomes and paracytic stomata. The lower epidermis is similar to the upper epidermis. Mesophyll of the leaf contains palisade and spongy parenchyma. Palisade is single-layered, compact with radially elongated tubular cells. Spongy parenchyma contains Six to eight layered loosely arranged, intercellular spaces parenchymatous cells with calcium oxalate crystals and lignified vascular strands.

Midrib of the leaf contains epidermis, vascular tissue. Epidermal layers are continuous, and collenchyma cells are present below the upper and above the lower epidermis (Thick-walled cellulose cells). The middle portion of the midrib contains cortical parenchyma and vascular tissue with needle-shaped raphides is present. Vascular tissue contains scattered Collateral vascular bundles of various sizes with lignified xylem, and nonlignified phloem and pericyclic fibre cells are present like a crown to the vascular bundle.

The transverses section of petiole contains epidermis and cortex [Fig. 2(B)].The epidermis comprises single-layered lignified rectangular cells with distinct wavy cuticle. Two to three-layered collenchyma cells are present below the epidermis. The cortex contains polyhedral parenchyma cell walls at the middle which are thickened, scattered vacuoles and scattered vascular bundles with lignified xylem and non-lignified Phloem are present. Pericyclic fibre cells are present like a crown to the vascular bundle. A few raphides were also observed in parenchyma cells.

The transverses section of the root contains cork, epidermis, cortex, Stele (endodermis, vascular bundle and pith [fig. 2(C)].Epidermis uniseriate, composed of a row of closely-set, a thin-walled cell with distinct wavy cuticle. Cortex is divided into three regions external, mean and inner cortex composed of gradually increasing the number of thick walls polyhedral

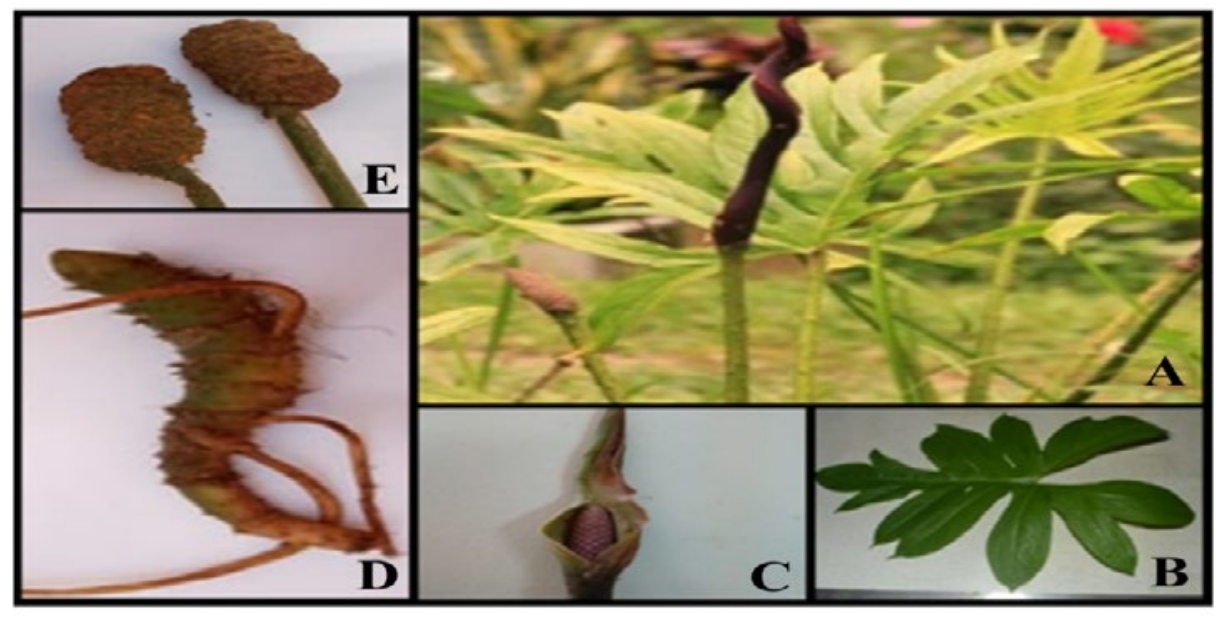

Fig. 1: Morphology of Lasia spinosa (L) Plant

(A) Whole Plant (B) Leaf (C) Inflorescence (D) Root and Rhizome (E) Fruit 


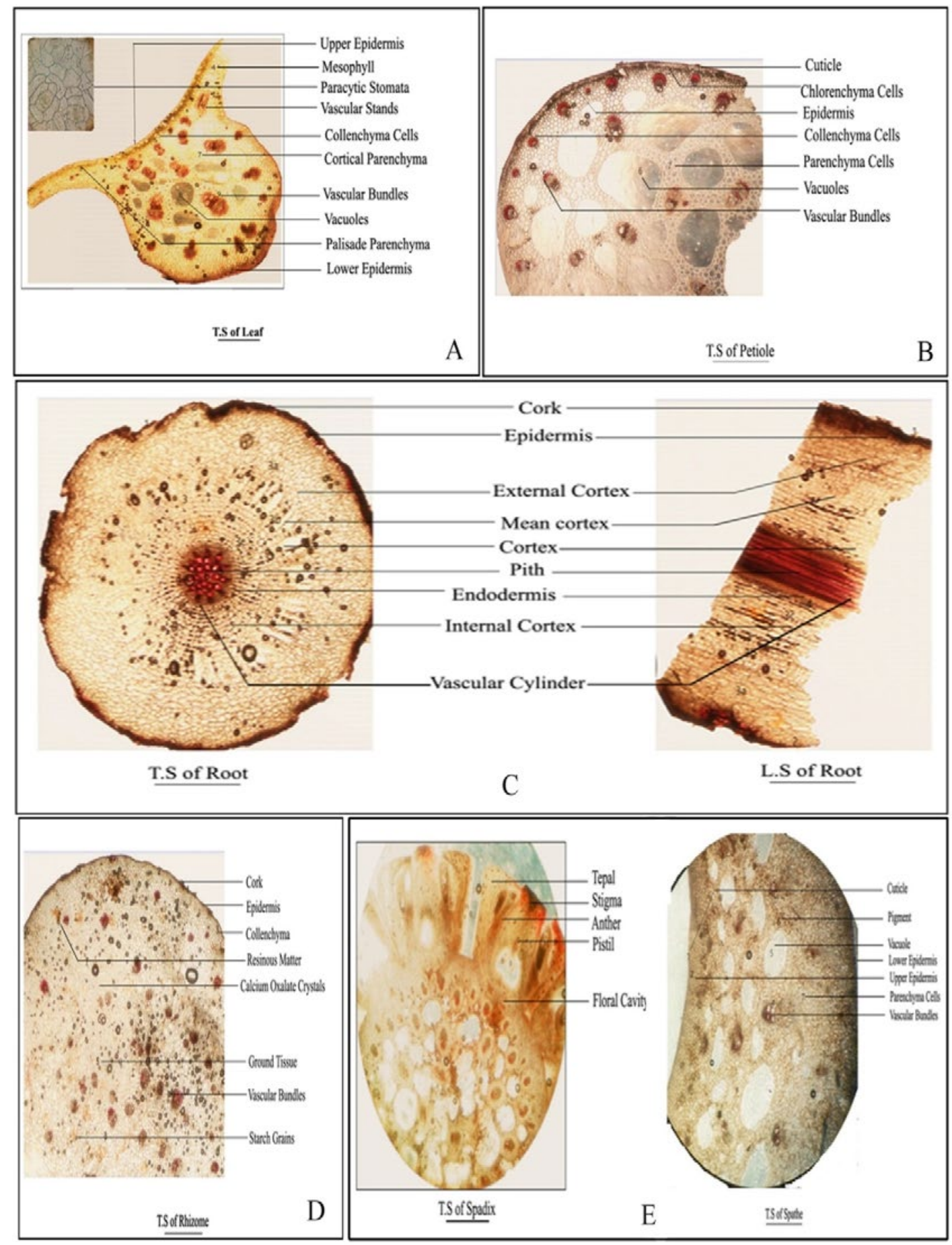

Fig. 2: Microscopic characteristics of different parts of Lasia spinosa (L)

(A) Transverse Section of leaf (B) Transverse Section of Petiole

(C) Transverse and Longitudinal section of Root

(D) Transverse Section of Rhizome (E) Transverse Section of Inflorescence

parenchymatous cells. The outer cortex is intact cortex contains parenchymatous cells, mean cortex contains radially arranged aerenchyma cells, and internal cortex contains cortical parenchyma cells. Stele-Endodermis is single-layered internal periclinical walls of endodermal cells with projections. The vascular cylinder contains radially arranged vascular bundles contains lignified xylem and non-lignified phloem. Pith is present in the middle.

The transverses section of rhizome contains cork, epidermis, Hypodermis, Ground tissue [fig. 2(D)].The epidermis comprises single-layered lignified rectangular 
cells with distinct wavy cuticle. Hypodermis includes three to four layers of parenchyma cells. Ground tissue contains scattered vascular bundles with lignified xylem and non-lignified Phloem. Pericyclic fibre cells are present like a crown to the vascular bundle. Also found calcium oxalate crystals, the abundant amount of starch grains and resinous substance.

The inflorescence of Lasia spinosa consists of three parts: the peduncle or stalk, the bract or spathe, and the spadix [Fig. 2(E)].Peduncle showed the same vascular features as of petioles. The upper and lower surfaces of the spathe have a thick cuticle, except for slightly lighter pigmentation in the lower epidermis, there is little anatomical difference between these surfaces. In the cross-section, just below the upper cuticle layer of the spathe is a single cell layer of epidermal cells. These cells are broad, rhomboid, and usually pentagonal. Beneath the epidermis is a single or double layer of isodiametric hypodermal cells. Similarly, the lower epidermis has a single cell layer composed of more typically tabloid cells. Between the upper and lower hypodermal layers are 10 to 12 irregularly arranged, layers of spongy parenchyma cells. Vascular bundles are dispersed at uniform intervals throughout the spathe.Spadix contains four fleshy perianth segments (tepals) envelop four stamens and a fleshy compound gynoecium. Each stamen is located opposite a tepal and pressed firmly against the gynoecium. At the periphery of the spadix, the tepals form the floral cavity and are attached to the central rachis. The floral cavity contains the stamens and carpel. Anatomically the tepals have an outer epidermal cell layer over ground parenchyma cells. Vascular bundles are interspersed throughout the ground cells. Many tepal cells contain druse and raphide crystals, more than any other cells in the anthurium plant. These crystals are found scattered throughout the plant, even in some epidermal cells. The stamen has a flat filament with a single vascular bundle in the centre, which traverses the entire filament and ends blindly in the connective tissue located between the two anthers. The anther is bilobed with each lobe containing two locules.

Powder microscopy of leaf showed polygonal irregular epidermal cells, lignified xylem vessels, paracytic stomata, needle-shaped calcium oxalate crystals polyhedral parenchymatous cells, spiral xylem, fibres are thickened, yellow walls.

Powder microscopy of petiole contains epidermal cells, xylem parenchyma, xylem vessels and fibres are thickened in the bundle of about 10-30 with crystal sheath of parenchymatous cells.

Powder microscopy of the root contains cork cells, epidermal cells, spiral xylem, and xylem vessels are irregular in shape, lignified and pitted contains calcium oxalate crystals.

Powder microscopy of rhizome showed polygonal irregular epidermal cells, xylem vessels, needle-shaped calcium oxalate crystals, fibres and the abundant amount of polygonal-shaped starch grains.

Powder microscopy characteristics of the various parts of Lasia spinosa (L) were observed [Fig. 3(A-D)]. The morphology of leaf epidermis shows that paracytic

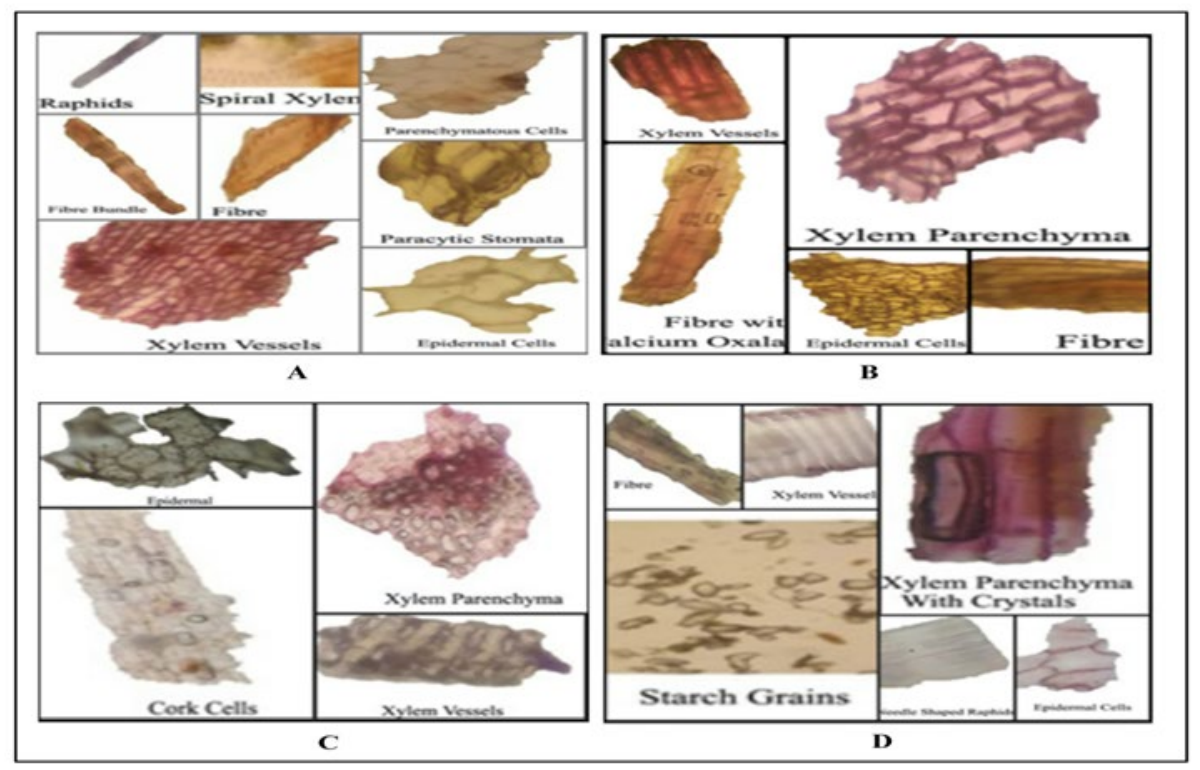

Fig. 3: Powder microscopic characteristics of different parts of Lasia spinosa (L)

Powder Characteristics of (A) Leaf (B) Petiole (C) Root (D) Rhizome 
stomata are present in both the surface. The epidermal layer consists of irregular walled polygonal cells [fig. 4].The stomatal index was found 17.14 per $\mathrm{mm}^{2}$. The length of stomata vary from 185.3-229 $\mu$, and the average length was found to be $207.15 \mu$ The width of stomata vary from 106.25-136.5 $\mu$, and average width was found to be $121.37 \mu$ [Table 1]. The venation pattern shows that the central vein is thicker than lateral veins, whereas vein islets are uniformly thin. Palinactindromous type of leaf venation, Co-arcuate type of venation is seen in each leaflet [Fig 1B]. Vein termination is long slender. Vein-islet no was found to be 12.34 per $\mathrm{mm}^{2} \&$ vein termination was found to be 24.69 per $\mathrm{mm}^{2}$. The average diameter of starch grains in rhizome powder found to be $175.826 \mathrm{~mm}$ [Table 1].

When the drug is available in the powdered form, studies of physicochemical parameters can serve as an essential source to measure the purity and quality of crude drugs. Ash values are utilized to establish the quality and purity of the crude drug. It implies the existence of various impurities like carbonate, oxalate and silicate. Here, acid insoluble ash was found to be less than total ash, water-soluble ash. Ash value is a measure of the quality and purity of the drug. The Crude fibre content values are an indicator of the proportion of husk in food products. The extractive values were determined to find out the amount of soluble active constituents compounds. Here, the aqueous extractive value is quantitatively more than that of the others. These are given in [Table 2]. Behaviours of the powdered drug of leaf, petiole, root, rhizome with different chemical reagents observed separately under daylight, and ultraviolet light and the changes in colour were also noted and tabulated in [Table 3-6].

Preliminary phytochemical evaluation:The plant material was subjected to initial phytochemical screening involving successive solvent extraction by different solvents in order of increasing polarity to obtain diverse polar and nonpolar phytoconstituents possessing different solubility pattern, followed by various chemical tests for the qualitative detection of various chemical constituents. The phytochemical investigation of varying solvent extracts viz., chloroform, methanol and water were examined, and it revealed the presence

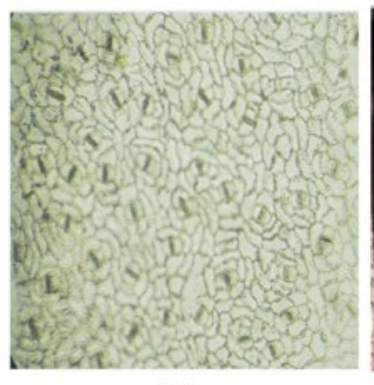

(A)

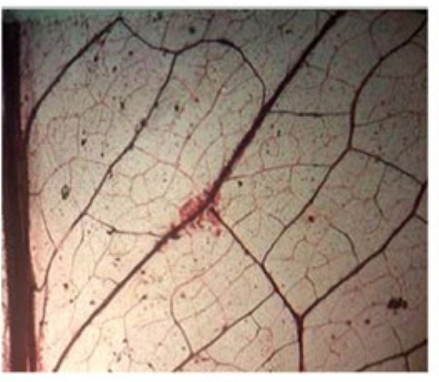

(B)

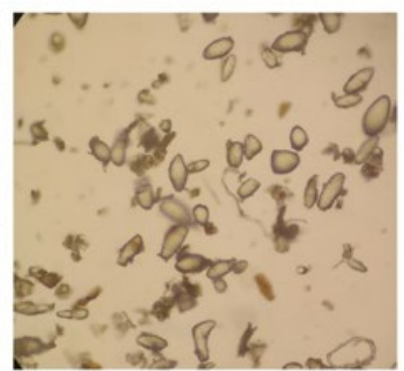

(C)

Fig. 4: Quantitative microscopic evaluation

(A) Micro morphology of leaf stomata

(B) Micro morphology of leaf Venation

(C) Micro morphology of starch grains

TABLE 1: QUANTITATIVE MICROSCOPIC EVALUATION

\begin{tabular}{lcc}
\hline S.No & Parameters & Values \\
\hline 1 & Stomatal index & $17.14{\text { per } \mathrm{mm}^{2}}^{2}$ \\
3 & Vein-islet number & $12.34 \mathrm{per} \mathrm{m}^{2}$ \\
4 & Vein termination number & $24.69 \mathrm{per} \mathrm{m}^{2}$ \\
5 & Palisade ratio & 7.4 \\
6 & Length of stomata & $185.3-229 \mu$ \\
7 & Average length of stomata & $207.15 \mu$ \\
8 & Width of stomata & $106.25-136.5 \mu$ \\
9 & Average width of stomata & $121.37 \mu$ \\
10 & Length of phloem fibre & $370.37-412.73 \mu$ \\
11 & Average length of phloem fibre & $391.55 \mu$ \\
12 & Width of phloem fibre & $17.62-38.04 \mu$ \\
13 & Average width of phloem fibre & $27.83 \mu$ \\
\hline
\end{tabular}


TABLE 2: PHYSICO-CHEMICAL ANALYSIS OF LEAF, PETIOLE, ROOT, RHIZOME OF LASIA SPINOSA

\begin{tabular}{lcccc}
\hline Name of the test $(\% \mathrm{w} / \mathrm{w})$ & Leaf & Petiole & Root & Rhizome \\
\hline Loss on drying & $8.11 \pm 0.03$ & $10.63 \pm 0.04$ & $8.35 \pm 0.04$ & $8.99 \pm 0.01$ \\
Total Ash value & $11.46 \pm 0.21$ & $9.0 \pm 0.05$ & $15.8 \pm 0.05$ & $7.75 \pm 0.03$ \\
Water soluble Ash value & $9.34 \pm 0.04$ & $5.2 \pm 0.03$ & $10.2 \pm 0.02$ & $6.8 \pm 0.04$ \\
Acid insoluble Ash value & $8.4 \pm 0.23$ & $3.2 \pm 0.02$ & $5.46 \pm 0.03$ & $5.80 \pm 0.02$ \\
Crude fibre content & $14.7 \pm 0.03$ & $75.9 \pm 0.13$ & $34.0 \pm 0.21$ & $36.1 \pm 0.02$ \\
Water soluble extractive value & $11.2 \pm 0.05$ & $15.3 \pm 0.03$ & $18.92 \pm 0.03$ & $42 \pm 0.03$ \\
Methanol soluble extractive value & $10.6 \pm 0.02$ & $13.9 \pm 0.02$ & $19.84 \pm 0.02$ & $11 \pm 0.12$ \\
Hexane soluble extractive value & $2.3 \pm 0.03$ & $1.23 \pm 0.15$ & $35.68 \pm 003$ & $2 \pm 0.12$ \\
Pet ether soluble extractive value & $1.4 \pm 0.03$ & $0.2 \pm 0.01$ & $6.72 \pm 0.01$ & $2 \pm 0.01$ \\
Chloroform soluble extractive value & $2.6 \pm 0.11$ & $2.4 \pm 0.21$ & $7.76 \pm 0.02$ & $2 \pm 0.02$ \\
Ethyl acetate soluble extractive value & $2.4 \pm 0.14$ & $3.6 \pm 0.11$ & $2.3 \pm 0.03$ & $22 \pm 0.03$ \\
Foaming index & $<100$ & $<100$ & $<100$ & $<100$ \\
\hline
\end{tabular}

All values are given as mean of 3 results $(n=3)$; SEM=Standard error of mean

TABLE 3: FLUORESCENCE ANALYSIS OF LEAF POWDER

\begin{tabular}{|c|c|c|c|c|c|}
\hline S.No & Reagents & Normal Light & UV Short & UV Long & Fluorescence \\
\hline 1. & Dry Powder & Green & Moss & Juniper & Light Mass \\
\hline 2. & Water & Light Green & Green & Pine Green & Pickle \\
\hline 3. & $50 \% \mathrm{H}_{2} \mathrm{SO}_{4}$ & Olive Green & Pear Green & Pickle & Moss \\
\hline 4. & $50 \% \mathrm{HCl}^{4}$ & Light Olive & Pickle & Pine & Olive Green \\
\hline 5. & $50 \% \mathrm{HNO}_{3}$ & Brown & Pine & Dark Moss & Peanut \\
\hline 6. & Conc. $\mathrm{H}_{2} \mathrm{SO}_{4}^{3}$ & Chocolate & Umber Brown & Mocha Brown & Chocolate \\
\hline 7. & Conc. $\mathrm{HCl}$ & Pickle & Moss & Pine & Crocodile \\
\hline 8. & Conc. $\mathrm{HNO}_{3}$ & Honey Orange & Pear & Juniper & Ochre \\
\hline 9. & Acetic Acid & Green & Dark Green & Juniper & Crocodile \\
\hline 10. & $5 \% \mathrm{FeCl}_{3}$ & Basil & Sea Weed & Juniper & Pine \\
\hline 11. & Picric Acid & Fern & Basil & Pine & Pickle \\
\hline 12. & Hexane & Pickle & Juniper & Pine & Pine \\
\hline 13. & Ethyl Acetate & Pickle & Juniper & Pine & See Weed \\
\hline 14. & $10 \% \mathrm{NaOH}$ & Light Green & Basil & Pine & Dark Pear \\
\hline 15. & $5 \% \mathrm{NaOH}$ & Dark Brown & Moss & Basil & Pickle \\
\hline 16. & $1 \mathrm{~N} \mathrm{NaOH}$ (Acq.) & Emerald & Pine & Juniper & Dark Pickle \\
\hline 17. & $1 \mathrm{~N} \mathrm{NaOH}$ (Alc.) & Dark Green & Umber Brown & Sea Weed & Dark Juniper \\
\hline 18. & Dil. $\mathrm{NH}_{3}$ & Pear Dark & Basil & Pine & Moss \\
\hline 19. & $\mathrm{I}_{2} \mathrm{H}_{2} \mathrm{O}^{3}$ & Pickle & Sea Weed & Pine & Moss \\
\hline 20. & Methanol & Green & Dark Weed & Dark Sea Weed & Sea Weed \\
\hline
\end{tabular}

TABLE 4: FLUORESCENCE ANALYSIS OF PETIOLE POWDER

\begin{tabular}{|c|c|c|c|c|c|}
\hline S.No & Reagents & Normal Light & UV Short & UV Long & Fluorescence \\
\hline 1. & Dry Powder & Pale Brown & Brown & Dark Brown & Pale Brown \\
\hline 2. & Water & Light Tortilla & Tortilla & Cedar Brown & Peanut Brown \\
\hline 3. & $50 \% \mathrm{H}_{2} \mathrm{SO}_{4}$ & Olive Green & Pecan Brown & Mocha Brown & Mass Green \\
\hline 4. & $50 \% \mathrm{HCl}$ & Tangerine Green & Ochre Brown & Brown & Honey Orange \\
\hline 5. & $50 \% \mathrm{HNO}_{3}$ & Dijon Brown & Peanut Brown & Spice Brown & Light Brown \\
\hline 6. & Conc. $\mathrm{H}_{2} \mathrm{SO}_{4}$ & Dark Chocolate & Umber Brown & Dark Umber & Chocolate \\
\hline 7. & Conc. $\mathrm{HCl}$ & Dijon Brown & Brown & Peanut Brown & Tortilla \\
\hline 8. & Conc. $\mathrm{HNO}_{3}$ & Honey Brown & Tortilla & Peanut Brown & Light Tortilla \\
\hline 9. & Acetic Acid & Light Tortilla & Mocha Brown & Cedar Brown & Peanut Brown \\
\hline 10. & $5 \% \mathrm{FeCl}_{3}$ & Juniper Green & Dark Brown & Umber Brown & Mocha Brown \\
\hline 11. & Picric Acid & Dijon Orange & Peanut Brown & Spice Brown & Brown \\
\hline 12. & Hexane & Light Brown & Cedar Brown & Dark Brown & Peanut Brown \\
\hline 13. & Ethyl Acetate & Light Brown & Mocha Brown & Dark Brown & Cedar Brown \\
\hline 14. & $10 \% \mathrm{NaOH}$ & Dijon Brown & Peanut Brown & Mocha Brown & Tortilla \\
\hline 15. & $5 \% \mathrm{NaOH}$ & Dark Tortilla & Wood Brown & Coffee Brown & Peanut Brown \\
\hline 16. & $1 \mathrm{~N} \mathrm{NaOH}$ (Acq.) & Dark Tortilla & Dark Peanut & Mocha Brown & Mocha Brown \\
\hline
\end{tabular}


www.ijpsonline.com

\begin{tabular}{lccccc} 
17. & $1 \mathrm{~N} \mathrm{NaOH}($ Alc. $)$ & Dark Peanut & Umber Brown & Dark Brown & Mocha Brown \\
18. & Dil. $\mathrm{NH}_{3}$ & Tortilla Brown & Pecan Brown & Pecan Brown & Peanut Brown \\
19. & $\mathrm{I}_{2} \mathrm{H}_{2} \mathrm{O}$ & Light Tortilla & Wood Brown & Mocha Brown & Brunette \\
20. & Methanol & Light Tortilla & Brown & Mocha Brown & Pale Brown \\
\hline
\end{tabular}

TABLE 5: FLUORESCENCE ANALYSIS OF ROOT POWDER

\begin{tabular}{|c|c|c|c|c|c|}
\hline S.No & Reagents & Normal Light & UV Short & UV Long & Fluorescence \\
\hline 1. & Dry Powder & Brown & Brown & Dark Brown & Brown \\
\hline 2. & Water & Tortilla & Peanut & Chocolate & Dark Tortilla \\
\hline 3. & $50 \% \mathrm{H}_{2} \mathrm{SO}_{4}$ & Tortilla & Pecan & Brunette & Peanut \\
\hline 4. & $50 \% \mathrm{HCl}$ & Pale Yellow & Peanut & Mocha & Dijon \\
\hline 5. & $50 \% \mathrm{HNO}_{3}$ & Fire & Peanut & Pecan & Honey \\
\hline 6. & Conc. $\mathrm{H}_{2} \mathrm{SO}_{4}$ & Tortilla & Pecan & Brunette & Peanut \\
\hline 7. & Conc. $\mathrm{HCl}$ & Light Tortilla & Peanut & Walnut & Tortilla \\
\hline 8. & Conc. $\mathrm{HNO}_{3}$ & Fire & Dijon & Spice & Golden Rod \\
\hline 9. & Acetic Acid & Brown & Walnut & Pecan & Spice \\
\hline 10. & $5 \% \mathrm{FeCl}_{3}$ & Carmel & Pecan & Brunette & Walnut \\
\hline 11. & Picric Acid & Tortilla & Pecan & Walnut & Peanut \\
\hline 12. & Hexane & Light Tortilla & Pecan & Walnut & Tortilla \\
\hline 13. & Ethyl Acetate & Ochre & Brunette & Chocolate & Brown \\
\hline 14. & $10 \% \mathrm{NaOH}$ & Ochre & Syrup & Spice & Cider \\
\hline 15 & $5 \% \mathrm{NaOH}$ & Ochre & Syrup & Spice & Cider \\
\hline 16. & $1 \mathrm{~N} \mathrm{NaOH}$ (Acq.) & Cider & Walnut & Syrup & Clay \\
\hline 17. & $1 \mathrm{~N} \mathrm{NaOH}$ (Alc.) & Brown & Walnut & Brunette & Spice \\
\hline 18. & Dil. $\mathrm{NH}_{3}$ & Tortilla & Syrup & Pecan & Peanut \\
\hline 19. & $\mathrm{I}_{2} \mathrm{H}_{2} \mathrm{O}$ & Cider & Walnut & Syrup & Clay \\
\hline 20. & Methanol & Brown & Walnut & Pecan & Spice \\
\hline
\end{tabular}

TABLE 6: FLUORESCENCE ANALYSIS OF RHIZOME POWDER

\begin{tabular}{|c|c|c|c|c|c|}
\hline S.No & Reagents & Normal Light & UV Short & UV Long & Fluorescence \\
\hline 1. & Dry Powder & Green & Moss & Juniper & Light Mass \\
\hline 2. & Water & Light Green & Green & Pine Green & Pickle \\
\hline 3. & $50 \% \mathrm{H}_{2} \mathrm{SO}_{4}$ & Olive Green & Pear Green & Pickle & Moss \\
\hline 4. & $50 \% \mathrm{HCl}$ & Light Olive & Pickle & Pine & Olive Green \\
\hline 5. & $50 \% \mathrm{HNO}_{3}$ & Brown & Pine & Dark Moss & Peanut \\
\hline 6. & Conc. $\mathrm{H}_{2} \mathrm{SO}_{4}$ & Chocolate & Umber Brown & Mocha Brown & Chocolate \\
\hline 7. & Conc. $\mathrm{HCl}$ & Pickle & Moss & Pine & Crocodile \\
\hline 8. & Conc. $\mathrm{HNO}_{3}$ & Honey Orange & Pear & Juniper & Ochre \\
\hline 9. & Acetic Acid & Green & Dark Green & Juniper & Crocodile \\
\hline 10. & $5 \% \mathrm{FeCl}_{3}$ & Basil & Sea Weed & Juniper & Pine \\
\hline 11. & Picric Acid & Fern & Basil & Pine & Pickle \\
\hline 12. & Hexane & Pickle & Juniper & Pine & Pine \\
\hline 13. & Ethyl Acetate & Pickle & Juniper & Pine & See Weed \\
\hline 14. & $10 \% \mathrm{NaOH}$ & Light Green & Basil & Pine & Dark Pear \\
\hline 15. & $5 \% \mathrm{NaOH}$ & Dark Brown & Moss & Basil & Pickle \\
\hline 16. & $1 \mathrm{~N} \mathrm{NaOH}$ (Acq.) & Emerald & Pine & Juniper & Dark Pickle \\
\hline 17. & $1 \mathrm{~N} \mathrm{NaOH}$ (Alc.) & Dark Green & Umber Brown & Sea Weed & Dark Juniper \\
\hline 18. & Dil. $\mathrm{NH}_{3}$ & Pear Dark & Basil & Pine & Moss \\
\hline 19. & $\mathrm{I}_{2} \mathrm{H}_{2} \mathrm{O}$ & Pickle & Sea Weed & Pine & Moss \\
\hline 20. & Methanol & Green & Dark Weed & Dark Sea Weed & Sea Weed \\
\hline
\end{tabular}


TABLE 7: PHYTOCHEMICAL ANALYSIS OF VARIOUS EXTRACTS OF LASIASPINOSA L. LEAF

\begin{tabular}{|c|c|c|c|c|c|c|c|}
\hline S.No & $\begin{array}{c}\text { Phyto } \\
\text { constituents }\end{array}$ & Method & $\begin{array}{l}\text { Hexane } \\
\text { extract }\end{array}$ & $\begin{array}{c}\text { Ethyl acetate } \\
\text { extract }\end{array}$ & $\begin{array}{c}\text { Chloroform } \\
\text { extract }\end{array}$ & $\begin{array}{c}\text { Methanolic } \\
\text { extract }\end{array}$ & $\begin{array}{l}\text { Aqueous } \\
\text { Extract }\end{array}$ \\
\hline \multirow{4}{*}{1} & \multirow{4}{*}{ Alkaloids } & Dragendroffs Test & - & - & - & - & + \\
\hline & & Wagner Test & - & + & - & - & + \\
\hline & & Mayers Test & - & + & - & - & + \\
\hline & & Hager's Test & - & + & - & - & + \\
\hline 2 & Sterols & Liebermann buchard test & + & + & + & - & - \\
\hline 3 & Triterpinoids & Salkowski test & + & + & + & - & - \\
\hline \multirow{2}{*}{4} & \multirow{2}{*}{ Tannins And Phenols } & $\mathrm{Fecl}_{3}$ Test & - & + & - & + & - \\
\hline & & Potassium dichromate test & - & + & - & + & - \\
\hline \multirow{3}{*}{5} & \multirow{3}{*}{ Flavanoids } & Shinoda Test & - & + & - & - & - \\
\hline & & Zn.Hydrocholride test & - & + & - & - & - \\
\hline & & Lead acetate Test & - & + & - & - & - \\
\hline 6 & Glycosides & General test & - & + & + & - & + \\
\hline 7 & Amino Acids & Ninhydrin test & - & + & - & + & - \\
\hline 8 & Volatile Oil & Stain test & - & - & - & - & - \\
\hline 9 & Saponins & Foam test & - & - & - & + & + \\
\hline 10 & Mucilage & Alcohol test & - & - & - & - & - \\
\hline 11 & Carbohydrates & Molisch's test & - & + & + & + & + \\
\hline 12 & Fats and oils & $5 \%$ Aq. $\mathrm{KOH}$ & + & - & - & - & - \\
\hline
\end{tabular}

TABLE 8: PHYTOCHEMICAL ANALYSIS OF VARIOUS EXTRACTS OF LASIASPINOSA L. PETIOLE

\begin{tabular}{|c|c|c|c|c|c|c|c|}
\hline S.No & $\begin{array}{c}\text { Phyto } \\
\text { constituents }\end{array}$ & Method & $\begin{array}{l}\text { Hexane } \\
\text { extract }\end{array}$ & $\begin{array}{c}\text { Ethyl acetate } \\
\text { extract }\end{array}$ & $\begin{array}{c}\text { Chloroform } \\
\text { extract }\end{array}$ & $\begin{array}{c}\text { Methanolic } \\
\text { extract }\end{array}$ & $\begin{array}{c}\text { Aqueous } \\
\text { Extract }\end{array}$ \\
\hline \multirow{4}{*}{1} & \multirow{4}{*}{ Alkaloids } & Dragendroffs Test & - & - & - & - & + \\
\hline & & Wagner Test & - & - & - & - & + \\
\hline & & Mayers Test & - & - & - & - & + \\
\hline & & Hager's Test & - & - & - & - & + \\
\hline 2 & Sterols & Liebermann buchard test & + & + & & + & - \\
\hline 3 & Triterpinoids & Salkowski test & + & + & + & + & - \\
\hline \multirow{3}{*}{4} & \multirow{2}{*}{$\begin{array}{l}\text { Tannins And } \\
\text { Phenols }\end{array}$} & $\mathrm{Fecl}_{3}$ Test & - & + & - & - & + \\
\hline & & Potassium dichromate test & - & + & - & - & + \\
\hline & & Shinoda Test & - & - & - & - & - \\
\hline \multirow[t]{2}{*}{5} & Flavanoids & Zn.Hydrocholride test & - & - & - & - & - \\
\hline & & Lead acetate Test & - & - & - & - & - \\
\hline 6 & Glycosides & General test & - & - & + & - & - \\
\hline 7 & Amino Acids & Ninhydrin test & - & - & - & + & - \\
\hline 8 & Volatile Oil & Stain test & - & - & - & - & - \\
\hline 9 & Saponins & Foam test & - & - & - & - & + \\
\hline 10 & Mucilage & Alcohol test & - & - & - & - & + \\
\hline 11 & Carbohydrates & Molisch's test & - & + & - & - & - \\
\hline 12 & Fats and oils & $5 \%$ Aq. $\mathrm{KOH}$ & - & - & - & - & - \\
\hline
\end{tabular}


TABLE 9: PHYTOCHEMICAL ANALYSIS OF VARIOUS EXTRACTS OF LASIASPINOSA L. ROOT

\begin{tabular}{|c|c|c|c|c|c|c|c|}
\hline S.No & $\begin{array}{c}\text { Phyto } \\
\text { constituents }\end{array}$ & Method & $\begin{array}{l}\text { Hexane } \\
\text { extract }\end{array}$ & $\begin{array}{c}\text { Ethyl acetate } \\
\text { extract }\end{array}$ & $\begin{array}{c}\text { Chloroform } \\
\text { extract }\end{array}$ & $\begin{array}{c}\text { Methanolic } \\
\text { extract }\end{array}$ & $\begin{array}{c}\text { Aqueous } \\
\text { Extract }\end{array}$ \\
\hline \multirow{4}{*}{1} & \multirow{4}{*}{ Alkaloids } & Dragendroffs Test & - & - & - & - & + \\
\hline & & Wagner Test & - & - & - & - & + \\
\hline & & Mayers Test & - & - & - & - & + \\
\hline & & Hager's Test & - & - & - & - & + \\
\hline 2 & Sterols & Liebermann buchard test & + & + & - & - & - \\
\hline 3 & Triterpinoids & Salkowski test & + & + & - & - & - \\
\hline \multirow{3}{*}{4} & \multirow[b]{2}{*}{ Tannins And Phenols } & $\mathrm{Fecl}_{3}$ Test & - & + & - & + & - \\
\hline & & $\begin{array}{c}\text { Potassium dichromate } \\
\text { test }\end{array}$ & - & + & - & + & - \\
\hline & \multirow{3}{*}{ Flavanoids } & Shinoda Test & - & - & - & + & + \\
\hline \multirow[t]{2}{*}{5} & & Zn.Hydrocholride test & - & - & - & + & + \\
\hline & & Lead acetate Test & - & - & - & + & + \\
\hline 6 & Glycosides & General test & - & - & - & - & + \\
\hline 7 & Amino Acids & Ninhydrin test & - & - & - & + & - \\
\hline 8 & Volatile Oil & Stain test & - & - & - & - & - \\
\hline 9 & Saponins & Foam test & - & - & - & - & + \\
\hline 10 & Mucilage & Alcohol test & - & - & - & - & - \\
\hline 11 & Carbohydrates & Molisch's test & - & - & - & + & + \\
\hline 12 & Fats and oils & $5 \%$ Aq. $\mathrm{KOH}$ & - & - & - & + & + \\
\hline
\end{tabular}

TABLE 10: PHYTOCHEMICAL ANALYSIS OF VARIOUS EXTRACTS OF LASIASPINOSA L. RHIZOME

\begin{tabular}{|c|c|c|c|c|c|c|c|}
\hline S.No & $\begin{array}{c}\text { Phyto } \\
\text { constituents }\end{array}$ & Method & $\begin{array}{l}\text { Hexane } \\
\text { extract }\end{array}$ & $\begin{array}{c}\text { Ethyl acetate } \\
\text { extract }\end{array}$ & $\begin{array}{c}\text { Chloroform } \\
\text { extract }\end{array}$ & $\begin{array}{c}\text { Methanolic } \\
\text { extract }\end{array}$ & $\begin{array}{c}\text { Aqueous } \\
\text { Extract }\end{array}$ \\
\hline \multirow{4}{*}{1} & \multirow{4}{*}{ Alkaloids } & Dragendroffs Test & - & - & + & - & + \\
\hline & & Wagner Test & - & - & + & - & + \\
\hline & & Mayers Test & - & - & + & - & + \\
\hline & & Hager's Test & - & - & + & - & + \\
\hline 2 & Sterols & Liebermann buchard test & + & + & + & - & - \\
\hline 3 & Triterpinoids & Salkowski test & + & + & + & + & - \\
\hline \multirow{2}{*}{4} & \multirow{2}{*}{$\begin{array}{l}\text { Tannins And } \\
\text { Phenols }\end{array}$} & $\mathrm{Fecl}_{3}$ Test & + & + & - & + & - \\
\hline & & Potassium dichromate test & + & + & - & + & - \\
\hline \multirow{3}{*}{5} & \multirow{3}{*}{ Flavanoids } & Shinoda Test & - & - & - & - & + \\
\hline & & Zn.Hydrocholride test & - & - & - & - & + \\
\hline & & Lead acetate Test & - & - & - & - & + \\
\hline 6 & Glycosides & General test & - & - & - & + & + \\
\hline 7 & Amino Acids & Ninhydrin test & - & - & - & + & - \\
\hline 8 & Volatile Oil & Stain test & - & - & - & - & - \\
\hline 9 & Saponins & Foam test & - & - & - & + & + \\
\hline 10 & Mucilage & Alcohol test & - & - & - & + & - \\
\hline 11 & Carbohydrates & Molisch's test & - & - & - & + & + \\
\hline 12 & Fats and oils & $5 \%$ Aq. $\mathrm{KOH}$ & - & - & - & + & + \\
\hline
\end{tabular}

of saponins, tannins, flavonoids, steroids, glycosides, alkaloids and volatile oils. Phytochemical parameters that can be useful in further isolation and purification of medicinally essential compounds [Tables 7-10].

\section{Acknowledgements:}

The authors were thankful to Andhra University College of Pharmaceutical Sciences, Andhra University for providing necessary laboratory facilities to carry out present research work.

\section{REFERENCES}

1. Keating R.C and Gregory M. Acoraceae and Araceae.USA: Oxford University Press.2002

2. Quattrocchi U. CRC world dictionary of medicinal and poisonous plants: common names, scientific names, eponyms, synonyms, and etymology (5 Volume Set). CRC press; 2012.

3. Hossain S, Khatun A, Miajee UE. Medicinal plants used by folk medicinal practitioners in three villages of Natore and Rajshahi districts, Bangladesh. Am Eur J Susta Agri 2010;4(2):211-8.

4. Temjenmongla T, Yadav AK. Anticestodal efficacy of folklore medicinal plants of Naga tribes in north-east India. African J Traditional, Complement Alternat Med 2005;2(2):129-33. 
5. Shefana AG, Ekanayake S. Some nutritional aspects of Lasia spinosa (kohila) 2009.

6. Alam F, Haque M, Sohrab H, Monsur MA, Hasan CM, Ahmed N. Antimicrobial and cytotoxic activity from Lasia spinosa and isolated lignan. Lat Am J Pharm 2011;30(3):550-3.

7. Brahma J, Chakravarty S, Rethy P. Qualitative Estimation of the Presence of Bioactive and Nutritional Compound in Lasia Spinosa: An Important Vegetable Plant used by the Bodos of Kokrajhar District. Int J Chem Tech Res 2014;6:1405-2.

8. World Health Organization. Quality control methods for herbal materials. World Health Organization, 2011.

9. Khandelwal KR. Practical pharmacognosy. Pragati Books Pvt. Ltd., 2008.

10. Harborne AJ. Phytochemical methods a guide to modern techniques of plant analysis. springer science \& business media; 1998.

11. Galani VJ, Patel BG. Psychotropic activity of Argyreia speciosa roots in experimental animals. Ayu 2011;32(3):380.

12. World Health Organization. Quality control methods for medicinal plant materials. World Health Organization, 1998. 